\title{
PENDIDIKAN DALAM PERSPEKTIF KRITIS-EMANSIPATORIS \\ (Telaah terhadap Kurikulum dan Metode Pembelajaran)
}

\author{
Yumidiana Tya Nugraheni, Agus Firmansyah \\ Doktoral UIN Sunan Kalijaga Yogyakarta yumidianatya@gmail.com \\ firmansyahjawari@yahoo.com
}

\begin{abstract}
Abstrak
The modern era is a time of development of the positivism philosophy. Modern world life is based on the paradigm of positivism thinking. The paradigm of positivism thinking believes that all science is mathematical which is characterized by objective, measurable, scientific, rational and universal thinking patterns. These four ways of thinking have brought modern civilization to the triumph of science. On the other side, a civilization based on the modern paradigm experiences various kinds of humanitarian problems. The paradigm of modern thinking is not suitable when it is associated with social problems including the education. Jurgen habermas, a Frankfurt school figure, offers solutions to overcome social problems that cannot be overcome by modern paradigms. Habermas developed a critical theory that had been put forward by the previous generation of Frankfrut figures. The theory he offered was a critical theory of emancipation and a theory of communicative action. Emancipatory critical theory and communicative action theory are able to answer problems in the world of education thatcannot be answered by the positivistic thinking paradigm.
\end{abstract}

Keywords: Critical Emancipatory, Communicative Action, Jurgen Habermas

\section{Pendahuluan}

Era kompetisi global yang memiliki ciri-ciri terbukanya akses informasi dan perdagangan bebas merupakan keniscayaan dalam dunia modern. Dunia modern didasarkan pada paradigma berfikir positivisme. Paradigma berpikir positivisme meyakini semua ilmu pengetahuan bersifat matematis. Sifat matematis ini ditandai dengan pola berpikir objektif, terukur, ilmiah, rasional dan universal. Empat cara berpikir tersebut telah mengantarkan peradaban modern pada kejayaan sains.

Di sisi lain peradaban yang didasarkan pada paradigma modern mengalami berbagai macam persoalan kemanusiaan. Persoalan kemanusiaan tersebut antara lain dehumanisasi, kolonialisme, krisis identitas dan fanatisme yang membabi buta. Banyak teori yang telah dikembangkan untuk mengatasi sisi gelap peradaban modern. Teori-teori tersebut kurang efektif dalam menyelesaikan permasalahan tersebut. Ketidak efektifan teori tersebut dikarenakan paradigma yang dikembangkan masih menggunakan paradigma berfikir modern. Paradigma berfikir 
modern tidak cocok ketika dikaitkan dengan permasalahan sosial. Permasalahan sosial yang bersifat temporal, lokal dan unik tidak efektif ketika didekati dengan paradigma objektif, seperti halnya pendidikan.

Pendidikan di suatu negara dengan negara lain memliki perbedaan dalam hal kebudayaan, bahasa, etika dan agama. Pendidikan yang mengacu pada paradigma objektif cenderung mengabaikan empat kekhususan tersebut serta memfokuskan pada ilmu matematika dan pengetahuan alam. Dampak dari pendidikan seperti ini akan menghasilakn output peserta didik yang mekanis dan terasing dari kebudayaannya. Dengan berbagai permasalahan tersebut diperlukan kritik yang bersifat kontruktif untuk membangun dunia pendidikan, sehingga tidak terjebak pada paradigma objektif yang akan menghasilkan lulusan yang mekanis. Salah satu trobosan untuk mengatasi permasalan tersebut adalah pendidikan model emansipatoris yang dipelopori oleh Jurgen Habermas.

\section{Pembahasan}

\section{Biografi Jurgen Habermas}

\section{Riwayat Hidup Jurgen Habermas}

Kota Dusseldorf Jerman merupakan kota kelahiran Jurgen Habermas pada 18 Juni tahun 1929 dan dibesarkan di kota Gumersbach, kota kecil dekat Dusseldorf. Latar belakang keluarganya, baik aya, ibu anak dan istrinya tidak banyak diketahui karena Habermas memiliki pembawaan diri yang pendiam, kehidupan pribadiya tidak pernah ditampakkan di depan publik. Meskipun demikian, ia diketahui memiliki seorang istri dan tiga orang anak. ${ }^{127}$

\section{Riwayat Akademik Jurgen Habermas}

Riwayat akademik Jurgen habermas dalam beberapa literatur hanya disajikan semenjak ia beajar di perguruan tinggi. Habermas mempelajari kesastraan, sejarah, filsafat, psikologi dan ekonoi di Universitas Gottingen. Ia meneruskan studi filsafatnya di Universitas Bonn Zurich dan meraih glar

\footnotetext{
${ }^{127}$ Michael Pusey, Habermas: Dasar dan Konteks Pemikirannya, (Yogyakarta: Resist Book, 2011), hal. 1
} 
doktor filsafat pada 1954 dengn disertasi berjudul "Das Absolute und die Geschichte" (yang absolute dan sejarah). ${ }^{128}$

Di usia 27 tahun, yaitu pada tahun 1956, Habermas mengajar di Institut Penelitian Sosial di Frankfurt yang telah berdiri sejak tahun 1923. Pada masa pemerintahan Nazi, institut ini sempat dibubarkan pada 1934 saat didirekturi oleh Max Horkheimer. Pada tahun 1951, instiut ini didirikan kembali dengan Theodor Wiesengrund Adorno sebagai direkturnya. Habermas adalah asisten Adorno yang mengajar filsafat dan sosiologi. Dari Adorno dan institut ini Habermas banyak belajar tentang sosiologi dan pemikiran marxisme. ${ }^{129}$

Jabatan sebagai Profesor Sosiologi dan Filsafat Universitas Frankfrut diraih Habermas pada tahun 1964. Selan kesibukan di University of Frankfrut,Habermas juga menjadi Profesor di bidang filsafat di Heidelberg Univerity pada 1961-1964. Selain itu, dalam beberapa waktu sering mengajar di New York Amerika.

Kepopuleran Habermas meningkat di mata para mahasiswa Jermanyang terkenal dengan sebutan "Gerakan Mahasiswa Kiri”. Namun, ketika aksi-aksi mereka menggunakan kekerasan menjelang tahun 1970, habermas dengan tegas mengemukakan kritiknya yang menyebabkan ia mengalami konflik dengan mahasiswanya. Pada tahun 1970, Habemas mengundurkan diri dari Universitas Frankfrut dan menerima tawaran bergabung dengan Institut Max Planck, Starnbeg yang konsen melakukan penelitian terhadap kondisi kehidupan dunia ilmiah-teknis. Pada 1972,Habermas ditunjuk menjadi direktur institut tersebut.

10 tahun setelah pengunduran dirinya, Habermas mulai kembali karirnya di Institut Max Planck, yang pada akhirnya institut pebelitian tersebut dibubarkan pada tahun. Selanjutnya, Habermas kembali ke Frankfrut sebagai seorang Filsafat dan Sosiologi. Ia mengajr di Universitas Frankfrut hingga tahun 1994. ${ }^{130}$

\footnotetext{
${ }^{128}$ K. Bertens, Filsafat Barat Kontemporer Inggris-Jerman (Jakarta: Gramedia,2002), hal. 236

${ }^{129}$ Bertens, Filsafat..., hal. 236

${ }^{130}$ Mukhrizal Arif, Pendidikan Postmodernisme (Yogyakarta: Ar-Ruzz Media, 2014), hal. 26.
} 


\section{Setting Sosial Jurgen Habermas}

Semasa Perang Dunia II kekuasaan Nazi, Habermas tumbuh sebagai remaja. Ketika menginjak usia 16 tahun, bertepatan degan berakhirnya Perang Dunia II, ia menyadari kejahatan yang dilakukan oleh rezim Nasionalis- Sosialis Hitler. Habermas mengingat ${ }^{131}$ :

Ketika berusia 15 atau 16, saya duduk di depan radio dan mengalami apa yang sedang didiskusikan di depan Pengadilan Nuremberg. Ketika orang-orang yang seharusnya tercengang oleh kengerian saat itu, mulai mempertanyakan keadilan pengadilan tersebut, pertanyaan pertanyaan prosedural dan pertanyaan jurisdiksi, terjadilah perpecahan pertama yang berlanjut hingga saat ini. Dapat dipastiakan, hanya karena saya masih sensitif dan mudah tersinggunglah saya tidak mudah menutup diri pada fakta tentang kekejaman yang diujudkan banyak orang dalam ukuran yang sama dengan mayoritas orang-orang sebelum saya.

Pengalaman masa muda yang berapi-api memberikannya keyakinan tentang pentingnya demokrasi dalam kehidupan bermasyarakat. ${ }^{132}$

\section{Genealogi Pemikiran Jurgen Habermas}

Diantara tokoh yang memengaruhi pemkiran Habermas dalam teori sosialnya antara lain: Karl Marx dan George Lukacs dengan filsafat sekaligus teori kritisnya. Max Weber dengan konsep rasionalisasi masyarakatnya. Imanuel Kant dengan idealisme historisnya dan kategorisasi rasionya. G.W. Frederich Hegel dengan konsep dialektika sejarahnya.

Max Horkheimer, Theodor W. Adorno dan Hubert Marcuse dalam kerangka besar teori kritis masyarakat. Emile Durkheim tentang pengertian dunia kehidupan. Talcott Parsons dan Niklas Luhmann tentang teori masyarakat sebagai suatu sistem. Edmund Hussrel, George Herbert Mead dan Alfred Schutz tentang pemahaan dunia kehidupan dan sosiologis fenoenologis. Martin Heidegger dan Hans George Gadamer dengan hermeneutik eksistensial mereka. Sigmund Freud dan Alfred Lorenzer dengan psikoanalisis dan rekonstuksi psikoanaisis. J.L. Austin dan John Searle dengan memanfaatkan teori perbuatan-tutur dalam analisisnya terhadap sifat khuus dari praktis komunikatif. Wilhelm Ditley tentang kkonsep Erkhlaren dan Verstehen. Jean

${ }^{131}$ Michael Pusey, Habermas..., hal. 2.

132 Mukhrizal Arif, Pendidikan..., hal. 26. 
Piaget dan Lawrence Kohlberg dalam pengembangan teori tentang kompetensi moral. Noam Chomsky tentang kompetensi linguisti. Ludwig Wittgenstein dengan linguistic analysis dalam ordinary language philosophy dan language game-nya. Charles Sanders Pierce, John Dewey dan James William tentang filsafat pragmatism, dan masih banyak lagi. ${ }^{133}$

\section{Teori Tindakan Komunikatif dan Teori Kritis Emansipatoris Jurgen Habermas}

Teori kritis disebut juga dengan madzhab Frankfrut karena semula berada di Institute fur Sozialforschung di Frankfrut Jerman. Cara pemikiran madzhab frankfrut disebut juga dengan "Teori Kritik Masyarakat". Maksud dari teori itu adalah pembebasan manusia dari jeratan dan tipu daya para teknokrat modern. ${ }^{134}$

Max Horkheimer, Herbert Marcuse dan Theodor W. Adorno yang disebut sebagai tokoh teori kritik generasi pertama merupakan tokoh utama teori kritik. ${ }^{135}$ Generasi pertama mengalamai kebuntuan dalam teori kritiknya. Generasi selanjutnya adalah Jurgen Habermas, ia adalah asisten dari Adorno dalam mengajar Filsafat dan Sosiologi di Universitas Frankfut, yang sekaligus mampu mengurai kebuntuan generasi pendahulunya.

Sebelum memahami teori tindkan komunukatif dan teori kritis emansipatoris, terlebih dahulu perlu dipahami konteks sejarah dari warisan tradisi pemikiran madzhab Frankfrut dimana dasar pemikiran Habermas berangkat dari sana. Warisan yang diterima diperoleh dari tradisi filsafat dan ilmu sosial Jerman. Tradisi ini diwariskan dari Kant, Hegel, Freud dan khususnya Marx. ${ }^{136}$ Kemudian tokoh penelitian frunkfrut seperti Max Horkheimer, Herbert Marcuse dan Theodor

W. Adorno melanjutkan tradisi pemikiran terebut. Habermas merupakan penerus dari para pendahulunya, namun Habermas tidak terjebak pada fanatisme tradisi. Dalam perkembangan teori sosialnya, Habermas banyak melakukan kritik terhadap para pendahulunya yang menyebabkan kebuntuan proyek institusi tersebut.

\footnotetext{
${ }^{133}$ Mukhrizal Arif, Pendidikan..., hal. 29.

${ }^{134}$ Franz Magnis Suseno, Filsafat sebagai Ilmu Kritis, (Yogyakarta: Kanisius, 1992), hal. 160.

${ }^{135}$ Ibid, hal. 161.

${ }^{136}$ M. Agus Nuryatno, Madzhab Pendidikan Kritis: Menyingkap Relasi Pengetahuan, Politikdan Kekuasaan,(Yogyakarta:Resist Book, 2008), hal. 12.
} 
Pada tahun 70-an, sejak Habermas pindah dari Universitas Frankfrut ke Max Planck Institute di kota Stanberg, teori komunikasi mulai dikembangkan dengan pengintegrasian linguistic-analysis dalam teori kritis. Unsur-unsur teori tentang bahasa, komunikasi, dan evolusi masyarakat dirumuskan oleh Habermas untuk memberikan dasar suatu kerangka normatif untuk mewujudkan tujuan emansipatoris. ${ }^{137}$ Pada tahun 1980-an karya besarnya The Theory of Comunicative Action, ${ }^{138}$ adalah titik awal usaha didialogkannya teori kritis yang disebut "teori tindakan komunikatif". ${ }^{139}$ Sejak awal, Habermas konsisten dngan minatnya yaitu pengembangan ke arah teori komunikasi. Dalam karya-karyanya di tahun 1960-an dapat ditemukan sebuah arah ke teori komunikasi, ketika ia masih berada di Universitas Frankfrut. Dari teori-teori inilah Haberms merumuskan beberapa teorinya.

Melanjutkan proyek kritis pendahulunya, Habermas menyataan bahwa metode ilmu pengetahuan dan ilmu sosial tidak pernah bebas nilai sebagaimana yang diklaim oleh positivistik. Ia akan selalu berkaitan dengan kepentingan. Dalam analisisnya, Habermas mengajukan tiga kepentingan yang menyelimuti ilmu pengetahuan dan ilmu sosial. Kepentingan tersebut ialah kepentingan teknis, kepentigan praksis dan kepentingan emansipatoris. ${ }^{140}$

Kepentingan teknis tercermin dari pendekatan empiris-analitis. Dalam mengamati objek penelitiannya, seorang peneliti menggunakan sistem acuan teknis terlebih dahulu untuk menetapkan aturan dalam proses penelitiannya. Contoh dari ilmu empiris-analitis adalah ilmu-ilmu alam. Ilmu-ilmu ini mencari hukum yang pasti, sehingga manusia dapat memanfaatkan alam demi kebutuhannya. ${ }^{141}$

Kepentingan yang kedua adalah kepentingan praksis yang tercermin dari pendekatan historis- hermeneutis yang digunakan. Ilmu hermeneutis terpancang pada sistem tindkan spesifik, yaitu sistem interaksi yang diperantarai oleh

\footnotetext{
${ }^{137}$ John Lechte, 50 Filsuf Kontemporer, terj. Gunawan Admiranto (Yogyakarta: Kanisius,2001), hal. 286.

138 Jurgen Habermas, The Theory of Communicative Action, (Boston: Beacon Press, 1989)

${ }^{139}$ Stephen K. White, The Cambridge Companion to Habermas, (USA: Cambridge UniversityPress, 1995), hal. 120.

${ }^{140}$ Fransisco Budi Hardiman, Menuju Masyarakat Komuikatif; Ilmu, Masyarakat, Politik, dan Posmodernisme Menurut Jurgen Habermas. (Yogyakarta: Kanisius, 2009), hal. 32.

${ }^{141}$ Franz Magnis Suseno, Filsafat..., hal. 183.
} 
bahasa. ${ }^{142}$ Kepentingan pada metode hermeneutis adalah memahai makna pada realitas. Contoh ilmu historis- hermeneutis adalah ilmu sejarah, ilmu dokumen sejarah dan ilmu penelitian arti-arti sejarah. Ilmu-ilmu ini adalah untuk memahami, lingkungannya adalah interaksi dan bahasa, tujuannya adalah penangkapan makna.

Kepentingan ketiga adalah kepentingan emansipatoris yang tercermin melalui metode ilmu kritis-emansipatoris. Pengetahuan yang didasaran pada kepentingan ini dihasilkan melalui refleksi diri. Proses refleksi diri atau pembentukan diri pengetahuan ini dilandasi oleh kepentingan emansipatoris dari manusia tersebut. Ilmu ekonomi, ilmu sosial dan politik, ilmu-ilmu refleksi seperti kritik ideologi, psikoanalisa dan filsafat adalah contoh dari ilmu kritis- emansipatoris. Kepentingan dari ilmu-ilmu ini adalah pembebasan, lingkungannya adalah kekuasaan dan metode dasarnya adalah merefleksikan sejarah subjek manusiawi secara kritis. ${ }^{143}$

Istilah emansipasi bukan hanya untuk membebaskan dari permasalahan sosial seperti perbudakan, penjajahan dan penindasan atas nama kekuasaan, namun juga dari permasalahan internal seperti gangguan psikis dan ketidaktahuan. Ciri dari emansipasi adalah bahwa seseorang telah berubah dari kondisi tidak tahu menjadi tahu. ${ }^{144}$ Emansipatoris di sini dimaknai sebagai pembebasan terhadap keterkungkungan, dogmatisme dan kendala kendala untuk mengukuhkan eksistensi kemanusiaan.

Habermas membedakan dua tindakan dasar manusia, yakni tindakan kerja dan tindakan komunikasi. Tindakan kerja (rasional-instrumental) maupun tindakan komunikatif adalah tindakan dasar manusia dalam kehidupannya. Dalam konteks sosial, tindakan komunikatif harus menjadi landasan manusia dalam berhubungan dengan sesamanya sebagai sesama subjek. Interaksi manusia adalah dengan perantara simboolsimbol yang sangat subjektif dalam memahaminya, oleh karena

\footnotetext{
142 Ibid, hal. 93.

${ }^{143}$ Franz Magnis Suseno, Filsafat..., hal. 183.

${ }^{144}$ Irfan Safrudin, Kritik Terhadap Modernisme(Studi Komparatif Jurgen Habermas danSayyed Hossein
} Nasr), disertasi, (Yogyakarta: IAIN Sunan Kaljaga, 2003), hal. 257. 
itu tindakan antara manusia harus senantiasa berdialog. ${ }^{145}$ Dari sinilah teori tindakan komunikatif dinamakan oleh Habermas.

Tindakan dibagi menjadi empat jenis oleh Habermas, yaitu tindakan tindakan teleologis, tindakan normative, tindakan dramaurgic, tindakan kounikatif. Dalam tindakan teleologis, tujuan khusus dipertahankan oleh aktor dan keputusan, yang menjadi konsep pokok itndakan ini, merupakan sebuah sarana yang tepat untuk dicapainya tujuan khusus. Tindakan normative adalah tindakan ang mana perilaku aktor tunggal bekanlah arah dari tindakan ini. Tindakan ini mengarah padaanggota-anggota kelompok sosial. Semua anggota kelompok sosial pada umumnya mempunyai nilai-niai yang berlaku yang menjadi acuan tindakan dalam kelopok tersebut. Dipenuhinya norma merupakan konsep utama tindakan ini. Tindakan dramaturgic, bahwa dalam tindakan jenis ini yang paling penting bukan perseorangan atau anggota kelompok, melainkan peserta yang bertindak yang ditujukan pada masyarakat umum atau pendengarnya. Penampilan di hadapan masyarakat atau biasa disebut dengan istilah "pencitraan" merupakan konsep pokok tindakan ini. Tindakan komunikatif, yaitu tindakan yang menunjuk kepada interaksi yang dilakukan dua orng atau lebih dengan kemampuan berbicra dan bertindak, serta dapat membentuk hubungan antar pribadi. Di sini aktor mencapai pemahaman terhadap situasi tindakan serta rencana tindakannya sendiri, serta tindakan terbaik atas dasar persetujuan. Interpretasi adlah konsep pokok dalam tindakan ini. Dalam interpretasi bahasa memiliki tempat yang utama. Untuk mencapai pemahaman dengan perantara bahasa diperlukan pengarahan, yaitu semacam mekanisme tindakan yang terkoordinasikan. 146

Dalam medium komunikasi melalui bahasa, manusia mengetahui sesuatu yang sangat penting, yaitu kebebasan. Karena mesikipun komunikasi antar manusia sering gagal karena perbedaan bahasa tidak saling mendengarkan ataau karena hal lainnya, namun manusia tetap tahu apa itu saling pengertian dan kapan itu tercapai. Saling engerti hanya mungkin bebas dari paksaan. Komunikasi hanya mungkit terjadi secara bebas. Dengan demikian, hubugan antar manusia perlu disusun

\footnotetext{
${ }^{145}$ Fransisco Budi Hardiman, Kritik Ideologi: Menyingkap Pertautan Pengetahuan dan Kepentingan Bersama Jurgen Habermas, (Yogyakarta: Kanisius, 2009) hal. 54 dan 108.

${ }^{146}$ Jurgen Habermas, Postmetaphisical Thinking Philosophical Essays, terj. William MarkHohengaten, (Great Britain: Polity Press, 1992), hal. 79-80.
} 
101 Mamba'ul 'Ulum, Vol.16 No.1, April 2020:93-111

melalui proses komuniksi antara semua yang bersangkutan dalam suatu komunikasi yang bebas kekuasaan. ${ }^{147}$

\section{Kontribusi Teori Tindakan Komunikatif dan Teori kritis emansipatoris Jurgen Habermas untuk Pendidikan}

Teori kritis dan teori tindakan komunikatif yang dirumuskan oleh Jurgen Habermas untuk sosiologi pendidikan menggunkan tolak ukur bagimana teori sosial memberikan pengaruh dalam membentuk pemikiran (thought) kemudian beranjak kepada ujaran (words) sehingga melahirkan tindakan (action) dan menjadi kebiasaan (habit) sehingga menjadi karakter (character) demi mewujudkan cita- cita dan tujuan (destiny) sosial yang transformatif, emansipatif dan demokratif. Tolak ukur ini menjadi kebutuhan untuk melihat bahwa menjadi manusia berarti menjadi pemikir, pembicara dan pelaku dalam konteks sosialnya. Arahan dari menjadi manusia tersebut akan membentuk kebiasaan sehingga menjadi karakter yang melekat. Cita-cita emansipasi seharusnya tidak melepaskan entitas manusia dalam pespektif sosialnya. Hal tersebut menjadi acuan bagi pertanyaan dasar bagaimana teori tindakan komunikatif memberi tawaran bagi pendidikan.

Banyak masalah sosial yang tidak tersinggung dalam proses belajar manusia dalam pendidikan. Pendidikan terjebak pada kerangka sistem yang mengekang setiap dimensi kehidupan manusia. Dengan demikian, muncul pertentangan antara idealitas yang hendak dicapai dengan sistemisasi yang dilakukan dalam pendidikan. Terjadinya sistemisasi pengelolaan proses belajar mengajar mengesankan kekakuan dan ketertutupan. Sistemisasi tersebut bertentangan dengan semangat peran serta masyarakat untuk menumbuhkan kesadaran kritis yang menjadi dasar eksistensi pendidikan dalam kehidupan masyarakat. ${ }^{148}$ Dengan adanya pagar sekolah, jam masuk-keluar, dan panduan panduan teknis dalam belajar mengajar menjadikan lahan belajar sosial yang berupa lingkungan tidak lagi menjadi prioritas pembelajaran untuk membentuk integrasi dan solidaritas sosial.

\footnotetext{
${ }^{147}$ Franz Magnis Suseno, Pijar Piijar Filsafat, (Yogyakarta: Kanisius, 2005), hal.158.

${ }^{148}$ Abdul Munir Mulkhan, "Pengantar" dalam Stevan M.Cham, Pendidikan Liberal Berbasis Sekolah, terj. Umi Yawisah (Yogyakarta: Kreasi Wacana, 2002), xxxviii
} 
Dengan kesadaran kritis, diharapkan akan mampu mengarahkan anak didik utuk menjadi bijaksana dalam tutur dan tingkah lakunya. Ia berbicara dengan berlandaskan pada penelitian yang cermat terhadap realita sosial. Ia bertindak berlandaskan pada pandangan dunia yang terbuka sehingga mampu melakukan kritik atas krisis yang terjadi dalam kehidupan sosial. Ia mampu melihat dengan jeliakar masalah yang melatarbelakangi krisis yang terjadi sekligus memberikan tawaran solusi untk mengatasi krisis tersebut. Dalam interaksi pendidkan anak didik bukan semata-mata objek dalam proses pembentukan pengetahuan. Seharusnya terjadi komunikasi dan dialog dalam proses belajar tersebut dengan memosisikan anak didik sebagai subjek dalam interaksi tersebut.

Kesadaran akan pentingnya komunikasi dalam dunia kehidupan manusia harusnya ditumbuhkan oleh guru dalam membentuk nila-nilai universal dari setiap partisipasi individu dalam membentuk kesepakatan bersama. Fungsi pendidikan sebagai pembentuk agen sosial untuk menciptakan suasana sosial yang lebih baik dan demokratis, guru harus mengarahkan anak didik kepada realitas sosial. Kepekaan terhadap permasalahan sosial harus disisipkan dalam kurikulum yang ada. Hidden curricullum-nya adalah mengarahkan anak didik untuk memiliki kepekaan terhadap realitas yang krisis yang tidak mencerminkan emansipasi.

Jika diamati lebih dalam, kepentingan yang berkecimpung dalam sistem pendidikan sampai saat ni masih pada taraf kepentingan teknis. Hal tersebut dapat terlihat dari bagaimana sistem tersebut dijalankan. Dalam proses belajar guru tidak memberikan pemahaman praksis dan emansipatoris. Guru datang dengan setumpukaturan yang disebut kurikulum yang diimplementasikan dalam petunjuk pelaksanaan kemudian dimanifestasikan dalam rancanngan acuan proses pembelajaran atau satuan acuan pembelajaran. Penerapan kepentingan teknis ini digunakan untuk menerapkan efisiensi dan efektifitas instruktural. Guru datang untuk menggugurkan tanggungjawab jam mengajar dan mengisi presensi guru sehingga profesi guru dihargai sebagai statistika kehadiran dan presensi. Murid hadir pada jam tertentu, kemudian dipresensi oleh petugas atau guru. Kepentingan emansipatoris nampaknya tidak punya harapan untuk hadir dalam pendidikan model ini. 
Nalar teknis-strategis seharusnya tidak merambah pada institusi sosial yang digadang-gadang menjadi tembok terdepan dalam mempertahankan sistem sosial kebudayaan dan nilai dalam masyarakat. Guru hendaknya memosisikan diri sebagai sesama subyek di hadapan anak didiknya dalam membentuk pengetahuan yang memuat kepentingan emansipasi. Artinya, harus ada komitmen untuk memperlakukan murid sebagai individu partisipan potensial dalam wacana pembentukan pengetahuan. Untuk membangun kesadaran emansipatoris, perlu dibagun basis pembelajaran yang terbuka dan dialogis. Dalam lingkungan pendidikan perlu ditingkatkan proses komunikasi melalui pemberdayaan dan kebebasan kritis anak didik. Pendidikan harus dapat mendorong kesetaraan dan demokrasi, mengembangkan otonomi dan tanggungjawab dalam diri anak, mengembangkan proses belajar yang koordinatif dan kolaboratif, melakukan diskusi dalam interaksi belajar, dan menjalankan pendidikan sosial yang mempelajari permasalahan sosial. ${ }^{149}$ Hal tersebut tentunya berdampak besar pada pendidikan, dalam konteks ini adalah muatan kurikulum dan metode pembelajaran.

\section{Kurikulum dan metode pembelajaran perspektif kritis -emansipatoris}

\section{Kurikulum}

Asal kata kurikulum adalah currir yang diartikan berlari dan curere yang diartikan tempat berpacu. Baik currir maupun curere adalah bahasa Yunani. ${ }^{150}$ Istilah kurikulum juga ada dalam bahasa latin "curriculum” yang pada awalnya memiliki arti "a running course, or race course, especially a chariot race cource" Selain itu, dalam bahasa prancis “courier' memiliki arti berlari. Dalam perkembangan selanjutnya penggunaan kata kurikulum digunakan dalam kaitannya dengan sejumlah mata pelajaran yang harus ditempuh demi tercapainya suatu gelar atau ijasah. ${ }^{151}$

Pengertian kurikulum yaitu memuat semua pengalaman yang semestinyadikuasai oleh anak didik dan guru membimbing hal tersebut. ${ }^{152}$ Sifat dari

\footnotetext{
${ }^{149}$ Keith Morrison, "Jurgen Habermas", dalam 50 Pemikir Pendidikan; dari Piaget sampaiMasa Sekarang, (Yogyakarta: Jendela, 2003), 391-392.

150 Abdullah Idi, Pengembangan Kurukulu Teori dan Praktik. (Yogyakarta: Ar-Ruzz Media, 2007), hal.183.

${ }^{151}$ S. Nasution, Pengembangan Kurikulum, (Bandung: PT Citra Aditya Bakti, 2003), 9

${ }^{152}$ Mangun Budiyanto, Pengantar Ilmu Pendidikan, (Yogyakarta: Fakutas Ilmu Tarbiyah danKeguruan UIN Sunan Kalijaga, 2013), 70.
} 
pengalaman dari anak didik dapat tertuang dalam intrakurikuler, kokurikuler maupun ekstra kurikuler di dalam maupun di luar kelas. Pengartian kurikulum dapat iartikan dan dipahai dalam cakupan yang sangat luas, termasuk kurikulum potensial, kurikulum aktual dan kurikulum tersembunyi atau hidden curriculum. ${ }^{153}$

Dalam pengembangan kurikulum, terdapat beberapa landasan, yaitu:

a. Landasan Filosofis, yaitu sistem nilai dari pandangan hidup. Filsafat bukan hanya terdapat pada individu, melainkan juga pada kelompok masyarakat atau suatu bangsa. Penyususnan kurikulum harus memperhatikan landasan filosofis suatu masyarakat tertentu atau bangsa, sehingga pelaksanaannya diarahkan kepada pembentukan manusia yang mempunyai sistem nilai yang lebih baik.

b. Landasan psikologis yang memiliki keyakinn bahwa individu merupakan wujud yang khas dari karakteristik psiko-fisiknya. Individu selalu berinteraksi dengan lingkungannya. Dalam penyususnan kurikulum hendaknya memprhatikan pengalaman belajar anak didik, motif yang mendorong anak didik dalam belajar, serta aktifitas anak didik dalam belajar agar penyajian kurikulum tidak mengalami disorientasi tuuan pendidikan.

c. Landasan sosial budaya, yaitu bahwa setiap lingkungan masyarakat memiliki sistem sosial budaya yang berbeda. Sistem sosial budaya tersebut mengatur pola kehidupan antar anggota masyarakat, anggota dan lembaga serta lembaga dan lembaga. Penyajian kurikulum hendaknya diselaraskan dengan aspek sosial-budaay masyarakat setempat sehingga sekolah dan masyarakat dapat aling mendukung.

d. Landasan Pertumbuhan dan Perkembangan anak didik, siswa merupakan bagian faktor penentu keberhasilan pendidikan. Dalam penyususnan kurikulum hendaknya mempertimbangkan dan memperhatikan tingkat pertumbuhan, perkembangan dan kematangan anak didik.

${ }^{153}$ Nana Sudjana, Pembinaan dan Pengembangan Kurikulum di Sekolah, (Bandung, sinar baru, 1991), 
e. Landasan organiasi kurikulum, secara garis besar, bentuk struktur organisasi kurikulum terdiri dari empat hal yaitu, subject curriculum, correlated curriculum, intergrated curricuum dan core curriculum. ${ }^{154}$

Dalam rancangan kurikuum, tiga kepentingan yang dapat membentuk pengetahuan yaitu kepentingan teknis, kepentigan praksis dan kepentingan emansipatoris, dapat menghasilkan tiga rancangan kurikulum, yaitu:

a. Kepentingan teknis yang memiliki pandangan rasionalis dan behavioris melihat kurikulum sebagai produk. Rancangn kurikulum dengan kepentingan teknis menghasilkan kurikulum instruental birokratis.

b. Kepentingan praksis yang memiliki pandangan humanistik, interpretatif dan pragmatis melihat kurikulum sebagai praktik.

c. Kepentingan emansipatoris yang memiliki pndangan eksistensialis dan kritik ideologi yang memberdayakan melihat kurikulum sebagai praksis untuk mewujudkan kepentingan emansipatoris. Daam hal ini pertanyaan- pertanyaan kurikuu seperti “kurikulu milik siapa?”, "untuk kepentingan siapa kurikulum dibuat?” dan “sejauhmana legitimasi kepentingan tersebut?" menjadi pertanyaan yang sangat diperhatikan. 155

Pengetahuan tidak bersifat netral. Kurikulum merupakan wilayah pertarungan ideologi. Menurut pandangn ini, pengetahuan yang diajarkan dalam pendidikan menunukkan bagaimana kelompok yang berkuasa memelihara kekuasaan melalui kurikulum. Kurikuum emansipatoris hendaknya dapat emnjadikan anak didik memaksimalkan potensi yang dimilikinya, mengembangkan demokrasi partisipatori, keterlibatan, hak suara anak didik dan perwujudan kebebasan eksistensial individu.

\section{Metode pembelajaran}

Metode, secara etimologi, berasal dari kata method yang berarti cara kerja yang tersusun dengan sistematis untuk memudahkan proses pelaksanaan

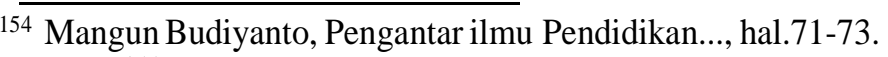

${ }^{155}$ Joy A. Palmer, Fifty Modern Thinkers on education: 50 Pemikir Paling BerpengaruhTerhadap Pendidikan Modern, (Yogyakarta:Irtisod, 2006), 367-368.
} 
untuk mencapai tujuan. ${ }^{156}$ Dalam bahasa arab, metode disebut țāriqūt. Dalam kamus besar bahasa Indonesia, metode adalah cara yang teratur dan berpikir baik untuk mencapai maksud. ${ }^{157}$ Dalam kaitannya dengan pembelajaran, metode berarti suatu cara yang dipakai dalam pembelajaran dengan tujuan agar anak didik mampu memahami, menguasai, materi-materi yang diberikan dalam proses pembelajaran. ${ }^{158}$

Secara terminologi, Ahmad Munjih Nasih dan Lilik Nur Kholidah mengutip pendapat para ahli yang telah mendefinisikan tentang metode, antara lain: pertama, menurut Arifin metode adalah jalan yang harus dilalui demi tercapainya tujuan. ${ }^{159}$ Kedua, menurut Hasan Langgulung, metode adalah cara yang harus dilalui guna tercapainya tujuan pendidikan. Ketiga, menurut Abd al-Rahmah al-Ghunaimah, metode adalah langkah-langkah yang praktis dalam mencapai tujuan pengajaran. Menurut Ahmad Tafsir ${ }^{160}$, metode adalah cara yang cepat dan tepat dalam mengajarkan mata pelajaran. Menurut Ramayulis, metode adalah seperangkat cara, jalan dan tehnik yang digunakan pendidik untuk mencapai tujuan pendidikan. ${ }^{161}$ Armai Arief mengutip pendapat Mahmud Yunus, metode adalah jalan yang harus ditempuh seseorang untuk mencapai tujuan. ${ }^{162}$ Berdasarkan beberapa definisi para ahli tersebut dapat ditarik kesimpulan bahwa metode adalah seperangkat cara, jalan, tehnik yang tepat

${ }^{156}$ Ahmad Munjih Nasih dan Lilik Nur Kholidah, Metode dan Teknik Pembelajaran dalamPendidikan Agama Islam, cet ke-2,(Bandung: Refika Aditama, 2013), hlm. 29.

${ }^{157} \mathrm{Ibid}$.

${ }^{158}$ Ibid. hlm. 30.

${ }^{159}$ Ibid.

${ }^{160}$ Ahmad Tafsir, Ilmu Pendidikan Dalam Perspektif Islam, cet ke-11 (Bandung: Rosda, 2014),hlm. 131.

${ }^{161}$ Ramayulis, Ilmu Pendidikan Islam, cet ke-8, (Jakarta: Kalam Mulia, 2010), hlm. 184-185.

162 Armai Arief, Pengantar Ilmu dan Metodologi Pendidikan Islam, (Jakarta: Ciputat Press,2002), hlm. 87. 
107 Mamba'ul 'Ulum, Vol.16 No.1, April 2020:93-111

dan cepat yang digunakan pendidik demi tercapainya kompetensi yang telah dirumuskan.

Dalam interaksi pendidikan atau proses belajar mengajar, anak didik bukan semata-mata objek dalam proses pembentukan pengetahuan. Seharusnya terjadi komunikasi dan dialog dalam proses belajar mengajar. Anak didik dan guru seharusnya diposisikan sebagai subjek dalam proses pembentukan pengetahuan. Kesadaran akan pentingnya komunikasi dalam dunia-kehidupan manusia harusnya ditumbuhkan oleh guru dalam membentuk nilai-nilai universal dari setiap partisipasi individu. Fungsi pendidikan adalah untuk membentuk agen sosial untuk menciptakan situasi sosial yang lebih baik dan demokratis.

Metode pembelajaran dalam kegiatan belajar mengajar hendaknya memanusiakan anak didik. Dalam mengajar di kelas, dapat dijabarkan delapan prinsip pendidikan yang komunikatif, yaitu: ${ }^{163}$

a. Perlunya kegiatan yang bersifat kooperatif dan kolaboratif

b. Kebutuhan akan kegiatan yang berdasarkan diskusi (discussion bassedwork)

c. Perlunya belajar mandiri, melalui pengalaman dan flekibel

d. Perlunya belajar melalui diskusi (negotiated learning)

e. Perlunya proses belajar yang terkait dengan komunitas agar anak didik dapat memahami dan menyelidiki berbagai lingkunga

f. Perlunya aktifitas pemecahan masalah

g. Perlunya memperbesar hak anak didik untuk berbicara

h. Perlunya guru untuk bertindak sebagai “intelektual transformatif" dengan mendorong kritik ideologi.

\section{Kritik Terhadap Pemikiran Habermas}

${ }^{163}$ Mukhrizal Arif, Pendidikan Postmodernisme (Yogyakarta: Ar-Ruzz Media, 2014), hal. 53. 
Habermas membagi keberadaan manusia dalam ranah subjek dan objek. Relasi manusia dengan alam dikenal dengan subjek-objek. Relasi ini cenderung memanfaatkan alam sesuai kepentingan mausia. Relasi manusia dengan dirinya subjek-itself. Relasi manusia dengan dirinya adalah manusia senatiasa memahami pola dan mekanisme roh dan jasadnya. Relasi manusia dengan manusia lain dikenal dengan subjek-subjek. Relasi ini mengajarkan manusia untuk senantiasa saling memahami orang lain.

Relasi habermas ini menjelaskan tentang paradigma berpikir filosof barat yang menafikan keberadaan tuhan dalam kehidupannya. Bagi filosof barat manusia merupakan sutradara dan aktor dalam kehidupan. Manusia bertugas subjek sekaligus objek. Keberadaan tuhan yang dinafikan berdampak pada paradigma berpikirnya. Habermas menempatkan kebertuhanan manusia pada kesadaran magis dan kesadaran naif. Penempatan kebertuhanan pada kesadaran magis membawa manusia para peradaban mistis. Peradaban yang lebih menekankan mitos. Sementara penempatan kebertuhanan pada peradaban naif membawa dampak falistik terhadap dunia. Inilah sumber dari permasalahan habermas yang menafikan relasi manusia dengan tuhan.

Islam merupakan salah satu agama yang cenderung membangun kesadaran kritis dan transformatif. Pembangunan kesadaran kritis dan transformatif dalam islam dalam ditinjau dari wahyu pertama yaitu surat al-alaq ayat 1-5. Surat ini dibuka dengan perintah untuk membaca. Membaca yang dimaksud pada ayat tersebut membaca realitas sosial, realitas budaya, realitas keberagamaan, dan realitas alam. Konsep pembacaan realitas inilah yang mengatarkan peradaban islammenjadi peradaban maju pada masa dinasti abbasiyah.

Berdasarkan hal tersebut habermas melakukan konsep generalisasi terhadap agama terutama tuhan. Habemas menggunakan pengalaman dan sejarah eropa dalam menentukan relasi manusia yang menjadi dasar ontologis, epistemologis, dan aksiologisnya. Habermas menafikan bahwa agama dan kebertuhanan memiliki dimensi subtansi, simbolik, penafsiran. Pemahaman ketiga dimensi tersebut bersifat parsial sehingga relasi manusia dan tuhan tidak dirumuskan dalam pemikiran jurgen habermas. 
109 Mamba'ul ‘Ulum, Vol.16 No.1, April 2020:93-111

\section{Kesimpulan}

Pendidikan adalah kunci dalam membentuk kesadaran masyarakat. Melalui output pendidikan sebagai agen sosial, proses kesadaran dan kedewasaan masyarakat terbentuk. Pembentukan masyarakat yang demokratif dapat diperoleh melalui proses pembentukan pemahaman bahwa tindakan komunikatif menjadi hal yag penting dalam berinteraksi.

Dalam kegiatan pendidikan, termasuk kegiatan belajar mengajar, hendaknya guru tidak lagi menempatkan anak didik sebagai objek, melainkan sebagai subjek. Dengan menempatkan anak didik sebagai subjek, tindakan komunikatif akan terwujud. Pendidikan yang dapat membentuk lingkungan perpikir kritis dan mencapai tahap tindakan komunikatif dalam lingkungannya, dapat dikatakan bawhapendidkan tersebut adalah pendidikan yang emansipatoris. 


\section{Daftar Pustaka}

Arief, Armai. 2002. Pengantar Ilmu dan Metodologi Pendidikan Islam. Jakarta:Ciputat Press.

Arif, Mukhrizal dkk.. 2014. Pendidikan Postmodernisme. Yogyakarta: Ar-RuzzMedia.

Bertens, K. 2002. Filsafat Barat Kontemporer Inggris-Jerman. Jakarta: Gramedia. Budiyanto,

Mangun. 2013. Pengantar Ilmu Pendidikan.Yogyakarta: Fakutas Ilmu Tarbiyah dan Keguruan UIN Sunan Kalijaga.

Charthy, Teori Thomas Mc. 2009. Kritis Jurgen Habermas, Diterjemahkan:Nurhadi. Bantul: Kreasi Wacana.

Habermas, Jurgen. 1989. The Theory of Communicative Action, Boston: BeaconPress.

Habermas, Jurgen. 1992. Postmetaphisical Thinking Philosophical Essays, Diterjemahkan: William Mark Hohengaten. Great Britain: Polity Press.

Hardiman, Fransisco Budi. 2009. Kritik Ideologi: Menyingkap Pertautan Pengetahuan dan Kepentingan Bersama Jurgen Habermas. Yogyakarta: Kanisius, 2009.

Hardiman, Fransisco Budi. 2009. Menuju Masyarakat Komuikatif; Ilmu, Masyarakat, Politik, dan Posmodernisme Menurut Jurgen Habermas. Yogyakarta: Kanisius. 
Idi, Abdullah. 2007. Pengembangan Kurukulu Teori dan Praktik. Yogyakarta: Ar- Ruzz Media.

Lechte, John. 2001. 50 Filsuf Kontemporer, Diterjemahkan: Gunawan Admiranto.Yogyakarta: Kanisius.Suseno, Franz Magnis. 1992. Filsafat sebagai Ilmu Kritis. Yogyakarta: Kanisius.

Nasih, Ahmad Munjih dan Lilik Nur Kholidah. 2013. Metode dan Teknik Pembelajaran dalam Pendidikan Agama Islam, cet ke-2. Bandung: Refika Aditama.

Nasution, S.. 2003. Pengembangan Kurikulum. Bandung: PT Citra Aditya Bakti. Nuryatno,

M. Agus. 2008. Madzhab Pendidikan Kritis: Menyingkap Relasi

Pengetahuan, Politik dan Kekuasaan. Yogyakarta: Resist Book.

Morrison, Keith. 2003. "Jurgen Habermas", dalam 50 Pemikir Pendidikan; dari Piaget sampai Masa Sekarang. Yogyakarta: Jendela.

Mulkhan, Abdul Munir. 2002. "Pengantar" dalam Stevan M.Cham, Pendidikan Liberal Berbasis Sekolah, terj. Umi Yawisah . Yogyakarta: Kreasi Wacana.

Palmer, Joy A.. 2006. Fifty Modern Thinkers on education: 50 Pemikir Paling Berpengaruh Terhadap Pendidikan Modern. Yogyakarta: Irtisod.

Pusey,Michael. 2011. Habermas: Dasar dan Konteks Pemikirannya, Yogyakarta: Resist Book.

Ramayulis. 2010. Ilmu Pendidikan Islam, cet ke-8. Jakarta: Kalam Mulia.

Safrudin, Irfan. 2003. Kritik Terhadap Modernisme (Studi Komparatif Jurgen Habermas dan Sayyed Hossein Nasr), Disertasi. Yogyakarta: IAIN Sunan Kaljaga.

Suseno, Franz Magnis. 2005. Pijar Piijar Filsafat. Yogyakarta: Kanisius.

Tafsir, Ahmad. 2014. Ilmu Pendidikan Dalam Perspektif Islam, cet ke-11. Bandung:Rosda.

White, Stephen K.. 1995. The Cambridge Companion to Habermas. USA: Cambridge University Press. 